\title{
To Prepare Oil Containing Vitex Negundo Extract Obtained Through Different Organic Solvents And Evaluate Its Anti- Inflammatory Activitiy By Topical Application.
}

\author{
Killol S Chokshi ${ }^{1}$, Jaimin S Suthar ${ }^{1}$, Divyesh B Ladola ${ }^{1}$, \\ Pratha K Patel ${ }^{1}$, Anupsinh J Solanki ${ }^{1}$, Aditya J Purohit ${ }^{1}$, Gaurav V Moradiya ${ }^{1}$, \\ Sandeep B Patel ${ }^{1}$, Dhagla R Chaudhary ${ }^{1}$, Kashyap K Bhatt ${ }^{1} \&$ Dilip Jani ${ }^{2}$, \\ ${ }^{1}$ Indukaka Ipcowala College Of Pharmacy, New V.V.Nagar, Gujarat - 388120. \\ ${ }^{2}$ Govinbhai Jorabhai Patel Ayurvedic Colleges, New V.V.Nagar, Gujarat - 388120.
}

\begin{abstract}
Vitex negundo has been used in massage oil as well as in traditional ayurveda as a potent pain reliever. The traditional Method of obtaining oil is simply based on taking water as the medium for extraction. The water extract obtained is then boiled with oil,till the water is completely evaporated. Here our aim is to replace water by different organic solvents and obtain oil which has much better efficacy than the traditionally extracted oil. The idea here is to obtain more efficacious oil than the marketed sample which is majorly extracted using water as solvent.Here the different organic solvents used are methanol, ethanol, petroleum ether and chloroform.The oil obtained was checked for its anti-inflammatory activity with the carrageenan induced rat paw edema. The prepared oil was compared with the marketed sample of mahanarayan oil. The methanolic extract has showed to be having high extract yield in literature.

Keywords: Carrageenan; Anti-inflammatory; Topical application; Oedema ; Potency.
\end{abstract}

\section{Introduction:}

Anti-inflammatory and analgesic are the most widely used class of drugs. Synthetically prepared drugs are their severe side effect of GIT distress and bronchoconstriction. The oil prepared from the herbal drugs will have no or less side effects as it will be applied topically and it will not undergo first pass metabolism.

Vitex negundo (Family:-Verbaneceae) has been used in massage oil as well as in traditional ayurveda as a potent pain reliever. It is one of the most potent herbal drug for relieving pain. Pluchea lanceolata(Family:Asteraceae) also popularly known as rasna has been used in ayurveda since early ages. The plants of Pluchea genus have been used traditionally used as astringent, antipyretic,anti-inflammatory, hepatoprotective, diaphoretic in fevers, smooth muscle relaxant, nervetonics, laxatives and for the treatment of dysentery.(Vishal $R$ Tandon,2005;Telang RS, Chatterjee S, Varshneya C.1999;Jana U, Chattopadhyay RN, Shaw BP,1999)

The Plant also contains many essential chemical constituents that give the effect of reliebing the pain. The constistuents like Taxasterol, vitexin are the main constituents. It also contains many other chemical constituents of different classes like glycosides,alkaloids, etc. They act by inhibiting the inflammatory mediators in the body.( Kirtikar KR, Basu B.D,2000; Wealth of India,1999)

Materials:

\section{Materials and Methods:}

The formulation contains the known potent drugs in ayurveda. This herb has been established as potent anti-inflammatory as well as analgesic action in the literature. The drug to be used in preparation of the formulation is Vitex negundo. Different organic solvents like methanol, ethanol, chloroform and petroleum ether were used for extracting. The formulation contained a suitable base which was sesame oil.

\section{Methods:}

1. Preparation of formulation:-

The plant parts were obtained from the botanical garden from the campus. The plants were collected and washed thoroughly and cut into small parts. The respective plant parts were allowed to shade dried and then boiled in about 5 times of volume of water/solvent until 2 times of water was left. The heating was continued for over two hours until 2 times of water was left. The left over water/solvent extract was filtered and boiled with the suitable base( Sesame Oil) until all the water/solvent is evaporated. The oil obtained was filtered for any residual particles if seen and was stored in suitable container as amber color container. Three different oil were prepared, one having more amount of Vitex negundo (25\% more than the actual concentration in other 
To prepare oil containing Vitex negundo extract obtained through different organic solvents and combination) and Pluchea lanceolata (25\% more than the actual concentration in other combination) respectively.( Chokshi KS,2012)

\section{Pharmcological activity :-}

The anti-inflammatory activity of the prepared poly herbal formulation was checked with the help of carrageenan induced rat paw edema model. The carrageenan was digested in saline for $24 \mathrm{hrs}$ before injecting it into the rat. The oil was applied on the hind rat paw before thirty minutes of the injecting the carrageenan solution. The observations for Inflammation were taken at regular intervals of one hour, two hour and twenty four hour. Comparisons of data were made to evaluate the efficacy of the oil with the marketed preparation of anti-inflammatory oil.( Buch M, Emery P.,2002; Katz L, Piliero SJ.,1969)

\section{Study Plan:}

\begin{tabular}{|c|c|c|c|c|c|c|}
\hline & \multicolumn{6}{|l|}{ Study plan } \\
\hline Group & I & II & III & IV & $\mathrm{V}$ & IV \\
\hline Treatment & $\begin{array}{l}\text { Normal } \\
\text { Control(carra } \\
\text { geenan) }\end{array}$ & $\begin{array}{l}\text { Standard } \\
\text { treatment(vo } \\
\text { veran gel) }\end{array}$ & $\begin{array}{l}\text { Treated with } \\
\text { Combinatio } \\
\mathrm{n} \text { I + } \\
\text { Carrageenan }\end{array}$ & $\begin{array}{l}\text { Treated with } \\
\text { Combinatio } \\
\text { n II + } \\
\text { Carrageenan } \\
\$\end{array}$ & $\begin{array}{l}\text { Treated } \\
\text { with } \\
\text { Combinatio } \\
\mathrm{n} \text { III + } \\
\text { Carrageena } \\
\mathrm{n}^{*}\end{array}$ & $\begin{array}{l}\text { Treated with } \\
\text { Combination } \\
\text { IV }{ }^{+} \\
\text {Carrageenan }^{+}\end{array}$ \\
\hline $\begin{array}{l}\text { Dose } \\
(\mathrm{mg} / \mathrm{kg} / \mathrm{da} \\
\mathrm{y})\end{array}$ & $1 \mathrm{ml}$ & $3 \mathrm{ml}$ & $3 \mathrm{ml}$ & $3 \mathrm{ml}$ & $3 \mathrm{ml}$ & $3 \mathrm{ml}$ \\
\hline $\begin{array}{l}\text { Number } \\
\text { of animals }\end{array}$ & 4 & 4 & 4 & 4 & 4 & 4 \\
\hline $\begin{array}{l}\text { Duration } \\
\text { of } \\
\text { treatment }\end{array}$ & Once & Once & Once & Once & Once & Once \\
\hline $\begin{array}{l}\text { Route of } \\
\text { administra } \\
\text { tion }\end{array}$ & $\begin{array}{l}\text { Sub- } \\
\text { cutaneous }\end{array}$ & $\begin{array}{l}\text { Topical } \\
\text { Application } \\
+ \text { S.C. }\end{array}$ & $\begin{array}{l}\text { Topical } \\
\text { Application } \\
+ \text { S.C. }\end{array}$ & $\begin{array}{l}\text { Topical } \\
\text { Application } \\
+ \text { S.C. }\end{array}$ & $\begin{array}{l}\text { Topical } \\
\text { Application } \\
+ \text { S.C. }\end{array}$ & $\begin{array}{l}\text { Topical } \\
\text { Application + } \\
\text { S.C. }\end{array}$ \\
\hline $\begin{array}{l}\text { parameter } \\
\mathrm{s} \text { to be } \\
\text { evaluated }\end{array}$ & Paw Volum & ll be evaluated & at different time & interval $(1,2,3$ & r) up to 24 ho & \\
\hline $\begin{array}{l}\text { Statistical } \\
\text { Analysis }\end{array}$ & $\begin{array}{l}\text { The data will } \\
\text { comparison t } \\
\text { combinations }\end{array}$ & $\begin{array}{l}\text { statisticall } \\
\text { to detern } \\
\text { optimizing }\end{array}$ & $\begin{array}{l}\text { aluated by } \\
\text { the level } \\
\text { efficacy of }\end{array}$ & $\begin{array}{l}\text { wav analy } \\
\text { significant } \\
\text { sil. }\end{array}$ & $\begin{array}{l}\text { f variance } \\
\text { ference b }\end{array}$ & $\begin{array}{l}\text { lowed by the } \\
\text { en different }\end{array}$ \\
\hline
\end{tabular}

Table 1: The Study Plan for the carrageenan induced rat paw inflammation model.( Surendra Kr Sharma,2011; William KSX, ,2011; Bansod M S,2011)

${ }^{\#}$ Combination I ---- Sesame Oil + extract of Vitex negundo in water.

${ }^{\$}$ Combination II --- Sesame Oil + extract of Vitex negundo in Methanol.

"Combination III -- Sesame Oil + extract of Vitex negundo in Chloroform.

Combination IV --- Sesame Oil + extract of Vitex negundo in Petroluem Ether.

\section{Experimental Animals:}

Albino Wistar rats weighing 160-240gm were procured from the college animal house with the prior permission of CPCSEA. Each group consisted of six rats each.

\section{CPCSEA NUMBER:}

IICP/UG/08-2011/03

\section{Result:}

The oil obtained was checked for its anti-inflammatory activity with the carrageenan induced rat paw edema. The prepared oil was compared with the marketed sample of mahanarayan oil. The methanolic extract has showed to be having high extract yield in literature. The result of the application of oil extracted by using methanol showed highest activity from all of the oils prepared using different organic solvents. 
To prepare oil containing Vitex negundo extract obtained through different organic solvents and

\begin{tabular}{|c|c|c|c|c|c|c|c|c|c|c|}
\hline & \multicolumn{3}{|c|}{ Initial Readings } & \multicolumn{3}{|c|}{ Readings after one hour } & \multicolumn{3}{|c|}{ Inflammation } & \multirow[t]{2}{*}{ Mean } \\
\hline & Rat 1 & $\underline{\text { Rat } 2}$ & Rat 3 & Rat 1 & Rat 2 & Rat 3 & Rat 1 & Rat 2 & Rat 3 & \\
\hline Combination I & 0.186 & 0.2 & 0.198 & 0.228 & 0.211 & 0.227 & 0.042 & 0.011 & 0.029 & 0.027333 \\
\hline Combination II & 0.176 & 0.19 & 0.17 & 0.205 & 0.211 & 0.195 & 0.029 & 0.021 & 0.025 & 0.025 \\
\hline Combination III & 0.171 & 0.18 & 0.185 & 0.186 & 0.248 & 0.201 & 0.015 & 0.068 & 0.016 & 0.033 \\
\hline Combination IV & 0.18 & 0.15 & 0.192 & 0.2 & 0.198 & 0.221 & 0.02 & 0.048 & 0.029 & 0.032333 \\
\hline Control & 0.199 & 0.174 & 0.166 & 0.257 & 0.231 & 0.224 & 0.058 & 0.057 & 0.058 & 0.057667 \\
\hline Standard & 0.165 & 0.155 & 0.157 & 0.207 & 0.195 & 0.192 & 0.042 & 0.04 & 0.035 & 0.039 \\
\hline
\end{tabular}

Table 2: The measurements obtained by digital vernier calipers after application of oil.

\begin{tabular}{|ll|c|}
\hline \multicolumn{2}{|c|}{ Extract(used for extracting active constituents) } & Activity \\
\hline 1. & Water & Good \\
\hline 2. & Methanol & Excellent \\
\hline 3. & Petroluem ether & Fine \\
\hline 4. & Chloroform & Fine \\
\hline
\end{tabular}

Table 3: The result of the different extracts used in conversion.

\section{Conclusion:}

The result of the application of oil extracted by using methanol showed highest activity from all of the oils prepared using different organic solvents. Alcohol as an extracting medium also showed good activity in alleviating the inflammation in the rat paw.

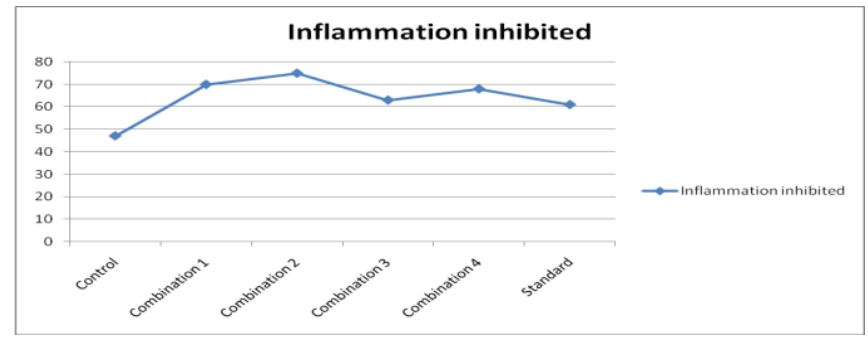

Graph 1: The graph shows the percent inflammation inhibited by the various combinations.

\section{Acknowledgement:}

The authors, mainly the team of seven erudites is very thankful to:

1> Dr. Dilip Jani - For developing our project and constantly motivating us.

2) Dr. Kashyap K Bhatt - Helping us out with the requirements and believing in our project.

3> Dr. Sandeep B Patel - For guiding us throughout the project work.

4> Mr. Dhagla R Chaudhary- For supporting us for the project work.

5> Mr. Keyur B Ahir- For encouraging us throughout the project.

\section{References:}

[1] Vishal R Tandon, Medicinal uses and biological activities of vitex negundo. Review article Vol 4/3 May 2005 (162-165).

[2] Telang RS, Chatterjee S, Varshneya C. Studies on analgesic and anti-inflammatory activities of Vitex negundo Linn. Indian Journal Pharmacol.1999; 31: (363-6).

[3] Jana U, Chattopadhyay RN, Shaw BP. Preliminary studies on anti-inflammatory activity of Zingiber officinale Rose, Vitex negundo Linn and Tinospora Cordifolia (willd) miers in albino rats. Indian J Pharmacol. 1999; 31: 232-3.

[4] Kirtikar KR, Basu B.D. Indian Medicinal Plants. Vol. I, 2nd ed., Oriental Enterprises, Dehradun, India, 2000.

[5] Wealth of India: A dictionary of Indian Raw materials and industrial products. (Revised), Council of Scientific and Industrial Research Publication, New Delhi, 1999.

[6] Chokshi KS et al., To Prepare a Poly Herbal Formulation Containing Pluchea lanceolata and Vitex negundo and Evaluate its Anti-Inflammatory Activity by Topical Application. American Journal of PharmTech Research 2012. ISSN 2249-3387.Vol 2,Issue 3,2012.

[7] Buch M, Emery P. The aetiology and pathogenesis of rheumatoid arthritis. Hosp Pharm 2002; 9: 5-10.

[8] Katz L, Piliero SJ. A study of adjuvant induced poly arthritis in the rat with special reference to associated immunological phenomena. Ann. New York Aca. Sci. 1969; 147: 515-36.

[9] Surendra Kr Sharma*and Naveen Goyal Department of Pharmaceutical Sciences, Guru Jambheshwar University of Science and Technology, Hisar, India.ISN 0976-1233. Annals of Biological Research,2011,2(3);25-34.

[10] William KSX, Bendito JM , Clarissa SL, Qt.al.,Topical anti-inflammatory action of Caryocar villosum Oil (Aubl) Pers.Journal of Applied Pharmacuetical Science 01(03);2011:62-67

[11] Bansod M S, Kagathara V G, Pujari R R, Patel V B , Ardeshna H H,Therapuetic effect of a poly-herbal preparation on adjuvant induced arthritis in Wistar rats.International Journal of Pharmacy and Pharmaceutical Sciences.ISSN-0975-1-491.Vol 3,Suppl 2, 2011 